Volume 16, No. 2, Juli 2019

Page: 783- 790

\title{
PERBAIKAN KUALITAS AIR MENGGUNAKAN GEL LIDAH BUAYA (Aloe vera)
}

\author{
Muhammad Fajar Pranata, Syarifudin A., Munawar Raharja \\ Poltekkes Kemenkes Banjarmasin Jurusan Kesehatan Lingkungan \\ Jl. H. Mistar Cokrokusumo No. 1A Banjarbaru Kalimantan Selatan 70714 \\ E-mail: m.fajar.pranata99@gmail.com
}

\begin{abstract}
Water Quality Improvement Using Aloe Vera Gel. Some people on the Trikora road, Sidomulyo Permai Ujung Complex, Banjarbaru City use swamp water with turbidity levels that do not meet the requirements, namely 42 NTU. Water sources that do not meet the requirements must be processed. Aloe vera as a natural coagulant contains mucilage which contains polygalluronic acid as a coagulant with the mechanism of adsorption and incorporation. This study aims to determine the effectiveness of dose and time variation of aloe vera gel contact as a natural coagulant in reducing turbidity of swamp water. This type of research is experimental, namely to determine the optimum dose and contact time of aloe gel as a natural coagulant. The design of this study uses Postest Only Design. Data analysis usingstatistical test Two Way Analysis of Variance with $\alpha=0.05$. Turbidity level analysis results decreased after treatment of variations in dose and contact time, the optimum dose of 1.2 grams in the contact time of 20 minutes was able to reduce turbidity of $41,63 \%$ with turbidity value of $10.73 \mathrm{NTU}, \mathrm{pH} 4.6$ and temperature of $28.5^{\circ} \mathrm{C}$. It can be suggested for further research there should be an addition of natural additives that are alkaline to increase the $\mathrm{pH}$ of the water.
\end{abstract}

Keywords: Swamp Water; Aloe Vera Gel; Turbidity

\begin{abstract}
Abstrak: Perbaikan Kualitas Air Menggunakan Gel Lidah Buaya (Aloe vera). Sebagian masyarakat jalan Trikora, Komplek Sidomulyo Permai Ujung Kota Banjarbaru menggunakan air rawa dengan tingkat kekeruhan yang tidak memenuhi syarat yaitu 42 NTU. Sumber air yang tidak memenuhi syarat harus dilakukan pengolahan. Lidah buaya sebagai koagulan alami mengandung mucilage yang mengandung asam poligalakturonat sebagai zat pengkoagulan dengan mekanisme adsorpsi dan penggabungan. Penelitian ini bertujuan untuk mengetahui efektifitas variasi dosis dan waktu kontak gel lidah buaya sebagai koagulan alami dalam menurunkan kekeruhan air rawa. Jenis penelitian ini adalah bersifat eksperimental yaitu untuk mengetahui dosis dan waktu kontak optimum gel lidah buaya sebagai koagulan alami. Desain penelitian ini menggunakan Postest Only Design. Analisa data menggunakan uji statistik Two Way Analisys of Variance dengan $\alpha=0,05$. Hasil analisis tingkat kekeruhan mengalami penurunan setelah dilakukan perlakuan variasi dosis dan waktu kontak, dosis optimum 1,2 gram dalam waktu kontak 20 menit mampu menurunkan kekeruhan 41,63\% dengan nilai kekeruhan 10,73 NTU, pH 4,6 dan suhu $28,5^{\circ} \mathrm{C}$. Dapat disarankan untuk penelitian selanjutnya perlu adanya penambahan bahan tambahan alami yang bersifat basa untuk menaikkan $p H$ air.
\end{abstract}

Kata Kunci: Air Rawa; Gel Lidah Buaya; Kekeruhan

\section{PENDAHULUAN}

Kondisi topografi di Kota Banjarbaru yang tergolong dataran tinggi rendah menyebabkan drainase air menjadi terhambat, hal ini dapat menyebabkan lahan air rawa dengan mudah terbentuk. Pada Jalan Trikora Komplek Sidomulyo Permai Ujung Kota Banjarbaru terdapat air rawa yang sering digunakan oleh sebagian masyarakatnya untuk keperluan sehari- hari seperti mandi dan mencuci. Air rawa sebenarnya dapat digunakan sebagai sumber air bersih, tetapi secara fisik air rawa tidak memenuhi persyaratan air bersih ditinjau dari segi kekeruhan. Berdasarkan penelitian Prahady S., dkk tahun 2014, diketahui bahwa air rawa memiliki tingkat kekeruhan 42,3 NTU[1]. Sedangkan standar air bersih menurut Permenkes No. 32 Tahun 2017, tingkat 
kekeruhan air bersih maksimal 25 NTU[2]. Sumber air yang tidak memenuhi syarat harus dilakukan pengolahan terlebih dahulu sebelum digunakan. Untuk mendapatkan air bersih, air harus diolah dengan berbagai cara baik secara fisika maupun kimia. Metode pengolahan air yang digunakan pada umumnya adalah pengolahan air secara fisika-kimia, yakni koagulasi-flokulasi yang kemudian diikuti dengan sedimentasi[3].

Penggunaan koagulan bahan alam dapat dilakukan sebisa mungkin untuk mengurangi penggunaan bahan sintetik yang menghasilkan efek samping dalam penggunaannya. Penggunaan koagulan bahan alam ini akan lebih murah dibandingkan dengan penggunaan koagulan sintetik yang biasa digunakan untuk pemurnian air[4]. Lidah buaya sebagai tumbuhan alami yang juga mengandung mucilage diharapkan dapat digunakan sebagai koagulan alami.

Mucilage yang terkandung di dalam lidah buaya mengandung asam poligalakturonat yang terbukti dapat menurunkan tingkat kekeruhan di dalam air[5]. Asam poligalakturonat berperan sebagai zat pengkoagulan dan mekanisme koagulasinya adalah adsorpsi dan penggabungan dimana pertikel yang tidak bersentuhan satu sama lain tetapi terikat pada senyawa asam poligalakturonat sehingga partikel-partikel di dalam air membentuk flok-flok ${ }^{[3]}$.

\section{BAHAN DAN CARA PENELITIAN}

Jenis penilitian ini merupakan penelitian eksperimen yaitu uji coba proses koagulasi, flokulasi dan sedimentasi dalam skala laboratorium dengan melakukan variasi dosis dan waktu kontak gel lidah buaya dan melakukan jartest untuk mendapatkan dosis dan waktu kontak optimum gel lidah buaya dalam menurunkan kekeruhan air rawa.

Desain atau rancang bangun penelitian yang digunakan adalah posttest with control group desaign. Desain atau rancang bangun penelitian yang digunakan adalah posttest with control group desaign. Rancangan ini dilakukan randomisasi, artinya pengelompokkan anggota-anggota kelompok kontrol dan kelompok eksperimen dilakukan berdasarkan acak atau random.

Sampel dalam penelitian ini adalah air rawa yang berada di Jalan Trikora, Komplek Sidomulyo Permai Ujung, Kota Banjarbaru. Metode yang digunakan dalam pengambilan sampel yaitu grab sampling dengan jumlah yang disesuaikan dengan kebutuhan dalam penelitian.

Bagian lidah buaya yang digunakan yaitu pada bagian daun lidah buaya. Daun lidah buaya dicuci dengan air bersih mengalir untuk menghilangkan kotorankotoran yang menempel. Selanjutnya pada bagian kulit dikupas, kemudian diambil bagian gel lidah buayanya dan dipotong menjadi beberapa bagian yang kecil-kecil, kemudian diletakkan pada wadah penampung dan siap digunakan.

Uji coba dosis gel lidah buaya yang digunakan terdiri dari variasi dosis yaitu 0,0 gram sebagai kontrol 0,4 gram, 0,8 gram, 1,2 gram, 1,6 gram dan 2,0 gram, yang kemudian di injeksikan ke masing-masing sampel tersebut pada 5 buah breaker glass yang berisi $1000 \mathrm{ml}$ sampel air rawa. Pengukuran dilakukan sebanyak 3 kali pengulangan. Sedangkan variasi waktu kontak yang digunakan yaitu 20 menit, 40 menit, dan 60 menit. Masing-masing sampel diaduk dengan alat flocculator. Pelarutan koagulan dilakukan dengan pengadukan cepat (30 detik; $200 \mathrm{rpm}$ ), pengadukan lambat (10 menit; $10 \mathrm{rpm}$ ), yaitu untuk membentuk flok-flok. Proses sedimentasi dilakukan untuk mengendapkan flok-flok yang telah terbentuk. Selanjutnya diukur tingkat kekeruhan, suhu, dan $\mathrm{pH}$.

Data dari hasil pengujian air rawa ditampilkan dalam bentuk tabel untuk menilai keefektifan variasi dosis dan waktu kontak gel lidah buaya sebagai koagulan alami dalam menurunkan kekeruhan air rawa. Selanjutnya hasil pengujian dibandingkan dengan Peraturan Menteri Kesehatan No. 32 Tahun 2017 tentang Standar Baku Mutu Kesehatan Lingkungan Dan Persyaratan Kesehatan Air Untuk Keperluan Hygiene Sanitasi, Kolam Renang, Solus Per Aqua Dan Pemandian Umum(2). Data hasil penelitian dianalisis secara 
statistik dengan uji annova yaitu two way

annova.

\section{HASIL PENELITIAN DAN PEMBAHASAN}

Berdasarkan penelitian didapatkan hasil pengukuran suhu, $\mathrm{pH}$, dan kekeruhan air rawa sebelum perlakuan dapat dilihat pada tabel 1. sebagai berikut :

Tabel 1. Hasil Pengukuran Kekeruhan Awal

\begin{tabular}{cccc}
\hline No. & Parameter & Hasil & Standar baku mutu \\
\hline 1. & Suhu & $28,3^{\circ} \mathrm{C}$ & Suhu udara \pm 3 \\
2. & $\mathrm{pH}$ & 5,8 & $6,5-8,5$ \\
3. & Kekeruhan & $42 \mathrm{NTU}$ & 25 NTU \\
\hline
\end{tabular}

Berdasarkan tabel diatas diketahui tingkat kekeruhan rata-rata air rawa sebesar 42 NTU dan pH sebesar 5,8 yang cenderung asam. Hal ini dapat diketahui bahwa air rawa tersebut tidak memenuhi standar baku mutu yang ditetapkan dalam Permenkes RI No. 32 Tahun 2017. Secara fisik air terlihat keruh dan asam sehingga diperlukan pengelolaan terlebih dahulu.

Hasil pengukuran penurunan kekeruhan, suhu dan $\mathrm{pH}$ air rawa sebagai kontrol sesudah perlakuan pengadukan dan variasi waktu kontak dapat dilihat pada tabel 2. sebagai berikut :

Tabel 2. Hasil Pengukuran Pada Kontrol Sesudah Perlakuan Pengadukan dan Waktu Kontak

\begin{tabular}{|c|c|c|c|c|c|c|}
\hline \multirow{2}{*}{ Replikasi } & \multirow{2}{*}{$\begin{array}{l}\text { Kekeruhan } \\
\text { Sebelum } \\
\text { Perlakuan } \\
\text { (NTU) }\end{array}$} & \multicolumn{3}{|c|}{ Kekeruhan Sesudah Perlakuan } & \multirow{2}{*}{$\begin{array}{l}\text { Suhu } \\
\left({ }^{\circ} \mathrm{C}\right)\end{array}$} & \multirow[b]{2}{*}{$\mathrm{pH}$} \\
\hline & & 20 menit & 40 menit & 60 menit & & \\
\hline 1 & \multirow{4}{*}{42} & 36,3 & 31,3 & 28,4 & \multirow{4}{*}{28,3} & \multirow{4}{*}{5,8} \\
\hline 2 & & 37,9 & 32,5 & 29,3 & & \\
\hline 3 & & 38,7 & 34,1 & 30,7 & & \\
\hline Rata-rata & & 37,63 & 32,63 & 29,46 & & \\
\hline $\begin{array}{l}\text { Persentase } \\
\text { rata-rata } \\
\text { penurunan } \\
\text { kekeruhan } \\
\quad(\%) \\
\end{array}$ & - & $10,40 \%$ & $22,31 \%$ & $29,85 \%$ & - & - \\
\hline
\end{tabular}

Berdasarkan tabel diatas penurunan kekeruhan air rawa pada dosis 0,0 gram atau tanpa penambahan koagulan yang diberikan perlakuan pengadukan dan variasi waktu kontak, diketahui dengan persentase sebesar 10,40 \% selama 20 menit, 22,31\% selama 40 menit dan $29,85 \%$ selama 60 menit. Untuk hasil suhu dan $\mathrm{pH}$ tidak ada perubahan, hal ini disebabkan karena tidak ada penambahan dosis koagulan pada air rawa tersebut.

Hasil pengukuran suhu air rawa dengan menggunakan alat termometer sesudah penambahan gel lidah buaya dan variasi waktu kontak dapat dilihat pada tabel 3. sebagai berikut : 
Tabel 3. Hasil Pengukuran Suhu Sesudah Penambahan Variasi Dosis dan Waktu Kontak

\begin{tabular}{|c|c|c|c|c|c|}
\hline \multirow{2}{*}{\multicolumn{2}{|c|}{$\begin{array}{c}\text { Perlakuan } \\
\text { (Dosis \& Waktu Kontak) }\end{array}$}} & \multicolumn{3}{|c|}{ Hasil Suhu dengan perlakuan $\left({ }^{\circ} \mathrm{C}\right)$} & \multirow{3}{*}{ Rata-rata } \\
\hline & & \multirow[b]{2}{*}{ r1 } & \multirow[b]{2}{*}{ r2 } & \multirow[b]{2}{*}{ r3 } & \\
\hline gram/L & Menit & & & & \\
\hline \multirow{3}{*}{$\begin{array}{c}0,0 \\
\text { (Kontrol) }\end{array}$} & 20 & 28,3 & 28,3 & 28,3 & 28,3 \\
\hline & 40 & 28,3 & 28,3 & 28,3 & 28,3 \\
\hline & 60 & 28,3 & 28,3 & 28,3 & 28,3 \\
\hline \multirow{3}{*}{0,4} & 20 & 28,3 & 28,5 & 28,7 & 28,5 \\
\hline & 40 & 28,7 & 28,8 & 28,3 & 28,6 \\
\hline & 60 & 28,6 & 28,2 & 28,3 & 28,4 \\
\hline \multirow{3}{*}{0,8} & 20 & 28,3 & 28,7 & 28,6 & 28,5 \\
\hline & 40 & 28,4 & 28,3 & 28,3 & 28,3 \\
\hline & 60 & 28,6 & 28,2 & 28,6 & 28,4 \\
\hline \multirow{3}{*}{1,2} & 20 & 28,8 & 28,2 & 28,6 & 28,5 \\
\hline & 40 & 28,3 & 28,6 & 28,8 & 28,6 \\
\hline & 60 & 28,4 & 28,6 & 28,5 & 28,5 \\
\hline \multirow{3}{*}{1,6} & 20 & 28,4 & 28,7 & 28,3 & 28,4 \\
\hline & 40 & 28,6 & 28,6 & 28,2 & 28,4 \\
\hline & 60 & 28,4 & 28,3 & 28,3 & 28,3 \\
\hline \multirow{3}{*}{2,0} & 20 & 28,3 & 28,9 & 28,6 & 28,6 \\
\hline & 40 & 28,6 & 28,2 & 28,8 & 28,5 \\
\hline & 60 & 28,7 & 28,3 & 28,7 & 28,5 \\
\hline
\end{tabular}

Berdasarkan tabel diatas hasil pengukuran suhu air rawa setelah perlakuan penambahan koagulan gel lidah buaya dan variasi waktu kontak yang berbeda-beda, tidak ada perubahan yang signifikan. Suhu air baik sebelum dan sesudah perlakuan masih berada dalam kisaran suhu normal.
Hasil pengukuran $\mathrm{pH}$ air rawa dengan menggunakan alat $\mathrm{pH}$ meter sesudah penambahan gel lidah buaya dan variasi waktu kontak dapat dilihat pada tabel 4 . sebagai berikut :

Tabel 4. Hasil Pengukuran pH Sesudah Penambahan Variasi Dosis dan Waktu Kontak

\begin{tabular}{|c|c|c|c|c|c|}
\hline \multicolumn{2}{|c|}{$\begin{array}{c}\text { Perlakuan } \\
\text { (Dosis \& Waktu Kontak) }\end{array}$} & \multicolumn{3}{|c|}{ Hasil pH dengan perlakuan } & \multirow[t]{2}{*}{ Rata-rata } \\
\hline gram/L & Menit & r1 & r2 & r3 & \\
\hline \multirow{3}{*}{$\begin{array}{c}0,0 \\
\text { (Kontrol) }\end{array}$} & 20 & 5,8 & 5,8 & 5,8 & 5,8 \\
\hline & 40 & 5,8 & 5,8 & 5,8 & 5,8 \\
\hline & 60 & 5,8 & 5,8 & 5,8 & 5,8 \\
\hline \multirow{3}{*}{0,4} & 20 & 5,2 & 5,0 & 5,1 & 5,1 \\
\hline & 40 & 5,0 & 5,0 & 5,1 & 5,0 \\
\hline & 60 & 5,2 & 5,1 & 5,3 & 5,2 \\
\hline \multirow{3}{*}{0,8} & 20 & 5,1 & 4,9 & 5,0 & 5,0 \\
\hline & 40 & 4,8 & 5,0 & 4,8 & 4,8 \\
\hline & 60 & 4,7 & 4,6 & 4,6 & 4,6 \\
\hline \multirow{3}{*}{1,2} & 20 & 4,2 & 4,8 & 4,9 & 4,6 \\
\hline & 40 & 4,4 & 5,0 & 4,3 & 4,5 \\
\hline & 60 & 4,0 & 4,5 & 4,2 & 4,2 \\
\hline \multirow{3}{*}{1,6} & 20 & 4,0 & 4,3 & 4,1 & 4,1 \\
\hline & 40 & 4,0 & 4,2 & 4,4 & 4,2 \\
\hline & 60 & 4,2 & 4,5 & 4,1 & 4,2 \\
\hline \multirow{2}{*}{2,0} & 20 & 4,5 & 4,3 & 4,2 & 4,3 \\
\hline & 40 & 4,3 & 4,5 & 4,0 & 4,2 \\
\hline
\end{tabular}




\begin{tabular}{cccccc}
\hline \multicolumn{2}{c}{$\begin{array}{c}\text { Perlakuan } \\
\text { (Dosis \& Waktu Kontak) }\end{array}$} & \multicolumn{2}{c}{ Hasil pH dengan perlakuan } & \multirow{2}{*}{ Rata-rata } \\
\hline Mram/L & Menit & r1 & r2 & r3 & \\
\hline & 60 & 4,0 & 4,1 & 4,4 & 4,1 \\
\hline
\end{tabular}

Berdasarkan tabel diatas hasil pengukuran $\mathrm{pH}$ menunjukkan setelah penambahan koagulan gel lidah buaya terjadi penurunan $\mathrm{pH}$. Hal ini disebabkan karena $\mathrm{pH}$ dari koagulan gel lidah buaya yang bersifat asam yaitu dengan $\mathrm{pH} 4-5$ (6). Penurunan $\mathrm{pH}$ tertinggi pada perlakuan penambahan dosis 1,6 gram dan waktu kontak 20 menit. Sedangkan penurunan $\mathrm{pH}$ terendah pada perlakuan penambahan dosis

Tabel 5. Hasil Pengukuran Kekeruhan Sesudah Penambahan Variasi Dosis dan Waktu

Kontak

\begin{tabular}{|c|c|c|c|c|c|c|}
\hline \multirow{2}{*}{\multicolumn{2}{|c|}{$\begin{array}{c}\text { Perlakuan } \\
\text { (Dosis \& Waktu } \\
\text { Kontak) }\end{array}$}} & \multicolumn{3}{|c|}{$\begin{array}{c}\text { Hasil Kekeruhan dengan } \\
\text { perlakuan (NTU) }\end{array}$} & \multirow{3}{*}{ Rata-rata } & \multirow{3}{*}{$\begin{array}{c}\text { Persentase } \\
\text { penuruan }(\%)\end{array}$} \\
\hline & & \multirow[t]{2}{*}{ r1 } & \multirow[t]{2}{*}{ r2 } & \multirow[t]{2}{*}{ r3 } & & \\
\hline $\operatorname{gram} / \mathrm{L}$ & Menit & & & & & \\
\hline \multirow{3}{*}{$\begin{array}{c}0,0 \\
\text { (Kontrol) }\end{array}$} & 20 & 36,3 & 37,9 & 38,7 & 37,63 & 10,40 \\
\hline & 40 & 31,3 & 32,5 & 34,1 & 32,63 & 22,31 \\
\hline & 60 & 28,4 & 29,3 & 30,7 & 29,46 & 29,85 \\
\hline \multirow{3}{*}{0.4} & 20 & 20,8 & 19,7 & 21,3 & 20,6 & 45,25 \\
\hline & 40 & 18,7 & 18,3 & 19,2 & 18,73 & 42,59 \\
\hline & 60 & 18,3 & 17,7 & 18,1 & 18,03 & 38,79 \\
\hline \multirow{3}{*}{0.8} & 20 & 13,9 & 14,3 & 13,7 & 13,96 & 62,90 \\
\hline & 40 & 12,2 & 12,4 & 11,8 & 12,13 & 62,82 \\
\hline & 60 & 10,8 & 11,6 & 10,3 & 10,9 & 63,00 \\
\hline \multirow{3}{*}{1.2} & 20 & 10,2 & 11,3 & 10,7 & 10,73 & 71,48 \\
\hline & 40 & 10,3 & 9,46 & 9,34 & 9,7 & 70,27 \\
\hline & 60 & 9,23 & 9,38 & 9,27 & 9,29 & 68,46 \\
\hline \multirow{3}{*}{1.6} & 20 & 12,3 & 13,4 & 12,1 & 12,6 & 66,51 \\
\hline & 40 & 11,8 & 12,3 & 11,6 & 11,9 & 63,53 \\
\hline & 60 & 11,2 & 10,9 & 11,3 & 11,25 & 61,81 \\
\hline \multirow{3}{*}{2.0} & 20 & 14,7 & 14,3 & 13,9 & 14,3 & 61,99 \\
\hline & 40 & 14,1 & 12,8 & 13,4 & 13,43 & 58,84 \\
\hline & 60 & 13,2 & 12,7 & 12,6 & 12,83 & 56,44 \\
\hline
\end{tabular}

Berdasarkan tabel diatas persentase penurunan kekeruhan paling tinggi pada perlakuan penambahan koagulan gel lidah buaya yaitu pada dosis 1,2 gram dan waktu kontak 20 menit dengan persentase penurunan sebesar $71,48 \%$. Sedangkan persentase penurunan kekeruhan paling rendah pada perlakuan penambahan koagulan gel lidah buaya yaitu pada dosis
0,4 gram dan waktu kontak 20 menit. Hasil juga menunjukkan bahwa $\mathrm{pH}$ air masih tidak memenuhi baku mutu air bersih yang ditetapkan yaitu 6,5 - 8,5.

Hasil pengukuran kekeruhan air rawa dengan menggunakan alat turbidimeter sesudah penambahan variasi dosis gel lidah buaya dan variasi waktu kontak dapat dilihat pada tabel 5. sebagai berikut : 
kekeruhan sampai $71,48 \%$ pada dosis 1,2 gram dalam waktu kontak selama 20 menit dengan nilai kekeruhan rata-rata 10,73 NTU. Sedangkan untuk hasil pengukuran $\mathrm{pH}$ menunjukkan terjadinya penurunan $\mathrm{pH}$ secara terus-menerus setelah penambahan variasi dosis. Hal ini disebabkan karena $\mathrm{pH}$ dari gel lidah buaya itu sendiri yang bersifat asam dengan kisaran $4-5$ karena mengandung asam poligalakturonat[6]. Asam poligalakturonat bekerja pada $\mathrm{pH}$ air yang memiliki kisaran yaitu 7-4[5]. Semakin besar konsentrasi koagulan yang ditambahkan semakin banyak proses hidrolisa dalam air sehingga ion-ion $\mathrm{H}^{+}$yang terionisasi dalam air tersebut akan semakin besar sehingga nilai $\mathrm{pH}$ akan semakin rendah (asam) [7]. Untuk hasil pengukuran suhu, tidak ada perubahan yang signifikan. Suhu air baik kontrol dan dengan perlakuan masih berada dalam kisaran suhu normal.

Persentase penurunan kekeruhan tertinggi yaitu pada dosis 1,2 gram dengan penurunan sebesar $71,48 \%$ dalam waktu kontak 20 menit. Dosis dan waktu kontak optimum dapat dikatakan bila dosis yang digunakan lebih sedikit dan waktu kontak yang diperlukan lebih cepat, sehingga dalam pengaplikasiannya dapat lebih hemat dan tidak merugikan dalam hal biaya dan waktu. Namun pada penambahan dosis 1,6 gram sampai dengan 2,0 gram terjadi peningkatan kekeruhan. Hal ini disebabkan karena jumlah koagulan yang lebih banyak dapat menyebabkan pembentukan flok tidak terjadi dengan baik yang dapat menimbulkan kekeruhan kembali[8].

Berdasarkan hasil uji Two Away Anova menunjukkan bahwa dosis dan waktu kontak mempunyai pengaruh signifikan terhadap kekeruhan karena nilai sig $(0,000)<\alpha(0,05)$. Berdasarkan uraian diatas dapat diketahui bahwa ada perbedaan kualitas air rawa sebelum ditambahkan gel lidah buaya dengan sesudah ditambahkan gel lidah buaya sebagai koagulan alami dalam menurunkan kekeruhan air rawa.

\section{KESIMPULAN DAN SARAN}

Lidah buaya efektif dalam menurunkan kekeruhan air rawa. Hasil suhu, $\mathrm{pH}$ dan kekeruhan air rawa sebelum pengolahan adalah suhu $28,3^{\circ} \mathrm{C}, \mathrm{pH} 5,8$ dan kekeruhan 42 NTU. Hasil sesudah pengolahan air rawa dengan menggunakan gel lidah buaya yaitu suhu masih dalam kisaran normal, $\mathrm{pH}$ masih belum memenuhi persyaratab dengan nilai 4,1, sedangkan tingkat kekeruhan mencapai 9,29 NTU dalam waktu kontak 60 menit dan sudah memenuhi persyaratan. Dosis optimum dan waktu kontak optimum gel lidah buaya berdasarkan hasil penelitian didapatkan yaitu 1,2 gram dengan persentase penurunan $71,48 \%$ dalam waktu kontak 20 menit dengan nilai kekeruhan sebesar 10,73 NTU.

Berdasarkan uji analisis statistik, ada perbedaan yang bermakna kualitas air rawa sebelum ditambahkan gel lidah buaya dengan sesudah ditambahkan gel lidah buaya sebagai koagulan alami dalam menurunkan kekeruhan air rawa dengan uji statistik menggunakan Two Away Anova dengan nilai sig $(0,000)<\alpha(0,05)$.

Diharapkan adanya penelitian lanjutan untuk penggunaan lidah buaya dalam mengatasi $\mathrm{pH}$ air yang menurun setelah penambahan gel lidah buaya.

\section{KEPUSTAKAAN}

1. Prahady S, Prahady S, Rumaiza A, Teknik J, Fakultas K, 2014. Universitas T. Pengolahan Air Rawa Menjadi Air Bersih Di Daerah.

2. RI. Peraturan Menteri Kesehatan Republik Indonesia Nomor 32 Tahun 2017 Tentang Standar Baku Mutu Kesehatan Lingkungan Dan Persyaratan Kesehatan Air Untuk Keperluan Higiene Sanitasi, Kolam Renang, Solus Per Aqua Dan Pemandian Umum. Kemenkes 2017.

3. Hengky P, Rama M. Penggunaan Gel Lidah Buaya ( Aloe Vera ) Sebagai Koagulan Alami Dalam Penjernihan Air Sumur Di Desa Sausu Tambu Kecamatan Sausu The Use Of Aloe Vera Gel (Aloe Vera) As A Natural Coagulant In Well Water Purification At The Sausu Tambu Village District Sa. 2016;5(1):16-22.

4. Idris J, Som Am, Musa M, Ku Hamid Kh, Husen R, Muhd Rodhi Mn. Dragon Fruit Foliage Plant-Based Coagulant For 
Treatment of Concentrated Latex Effluent: Comparison of Treatment With Ferric Sulfate. J Chem. 2013;2013(October 2012).

5. Pichler T, Young K, Alcantar N. Eliminating Turbidity In Drinking Water Using The Mucilage of A Common Cactus. Water Sci Technol Water Supply. 2012;12(2):179-86.

6. Padmadisastra, Yudi., Sisik. Sa. Formulasi Sediaan Cair Gel Lidah Buaya. Simp Nas Kim Bahan Alam Iii. 2003;18-9.

7. Rusdi, Sidi Tbp, Pratama R. Pengaruh Konsentrasi Dan Waktu Pengendapan Biji Kelor Terhadap Ph, Kekeruhan, Dan Warna Air Waduk Krenceng. J
Integr Proses [Internet]. 2014;5(1):4650. Available From: Http://Jurnal.Untirta.Ac.Id/Index.Php /Jip/Article/View/34

8. Yuliastri Ir. Penggunaan Serbuk Biji Kelor (moringa olefera) sebagai koagulan dan flokulan dalam perbaikan kualitas air limbahdan air tanah. 2010. Universitas Islam Negeri Syarif Hidayatullah, Jakarta.

9. Pranata, Muhammad Fajar. Efektifitas Variasi Dosis dan Waktu Kontak Gel Lidah Buaya (Aloe vera) Sebagai Koagulan Alami Dalam Menurunkan Kekeruhan Air Rawa. 2019. Poltekkes Kemenkes Banjarmasin, Banjarabaru. 
